\section{HIGHLY DESIRABLE ORAL CARE PRODUCTS}

WhiteWash Laboratories will be appearing again at this year's BDTA Dental Showcase with a strong presence at the CTS Dental Supplies stand (J01).

It's been a busy year for the WhiteWash team, with 2013 marking the launch of a number of highly desirable oral care products. These include the brand new Sonic Whitening Toothbrush, Whitening Remineralising Toothpaste, Teeth Whitening Gel (for tray whitening), and a new stronger version of the company's popular Professional Whitening Strips.

Visitors to the CTS stand will be able to chat in person with members of the WhiteWash team and see for themselves the fantastic "practice building' potential the premium branded WhiteWash products have to offer. With existing products including the

\section{COMPLETE DENTAL SOLUTIONS}

Find complete dental solutions by visiting the dbg stand (C07) at this year's BDTA Dental Showcase.

dbg can supply you with everything from day-to-day materials and sundries to equipment including dental chairs, handpieces and ultrasonic baths. In addition to their exclusive Tekpro range of dental materials and sundries dbg also stock industry recognised brands
Nano-Silver Whitening Toothbrush and Professional Whitening Toothpaste with Silver Technology, WhiteWash has established a strong brand of high quality oral care products that are ideally suited to driving practices' product sales. To learn more about WhiteWash products, and the latest additions to the WhiteWash range, make sure you visit the CTS stand (J01) at this year's Dental Showcase.

\section{www.whitewashlaboratories.com}

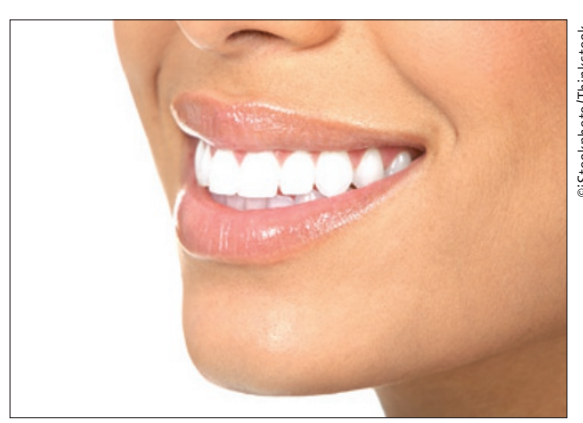

including: A-Dec, Bambi, Bien Air, Prestige Medical, DENTSPLY, NSK, and sdi dental ltd.

dbg also provide services in other key areas including engineering, compliance, training, and business services. These services are available at a special discount to dbg members, and provide dedicated high quality, cost-effective solutions to meet your every need.

Visit stand C07 or call dbg on 01606 861950 or visit www.thedbg.co.uk.

\section{DESIGN PREMISES UNIQUE TO YOU}

The Tavom UK experts are dedicated to helping you design an efficient working environment that encourages staff satisfaction, while making the most of space.

All Tavom UK cabinetry is made for maximum durability and is easily cleanable for full compliance with
HTM 01-05 regulations. It is also available in a range of colours, finishes and surfaces materials.

Whether it is your dental practice or laboratory in need of a new lease of life, be sure to visit Tavom UK at stand Q03 at BDTA Dental Showcase 2013.

www.tavomuk.com

\section{EDUCATION FOR EVERYONE}

Dedicated to providing top quality education for all members of the dental team, Healthcare Learning: Smile-on offers a wide range of learning opportunities.

From eLearning Libraries that enable you to choose what you want to study, to tooth whitening courses with expert Dr Wyman Chan, to practice management support with The Definite Guide, there really is something for everyone.

Additional qualifications available include the MSc in Healthcare Strategy \& Performance provided with Plymouth University Peninsula Schools of Medicine \& Dentistry, as well as primary qualifications in dental nursing.

The team for Healthcare Learning: Smile-on will be on hand at BDTA Dental Showcase 2013, ready to provide any information or advice you may need to develop your career.

Details will also be available on the recently launched Smile-on News website, designed to keep you updated with all the latest advancements in the profession.

Realise how easy that next step is with Healthcare Learning: Smileon - stand H01 at BDTA Dental

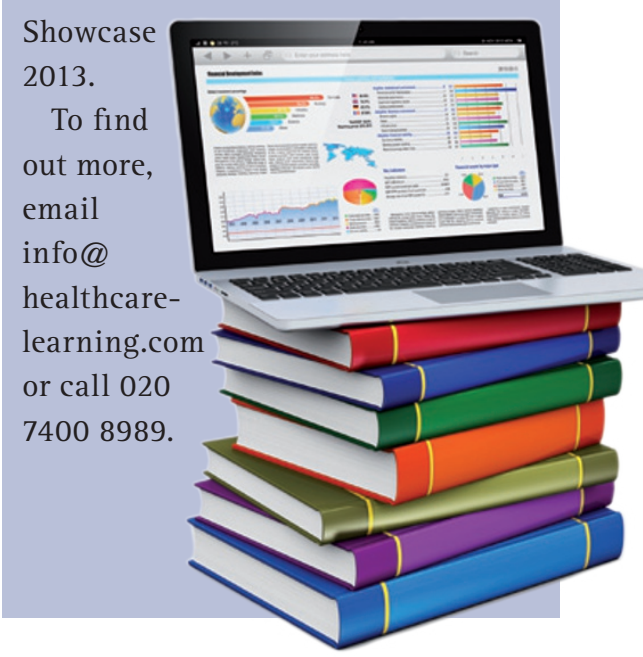

from mortgages to income protection.

To speak with a member of the money4dentists team visit stand E16b at this year's BDTA Dental Showcase.

For more information call 0845345 5060 or visit www.money4dentists.com. 